particularly in a mobile service in which flexibility is limited. Furthermore, its use may affect acceptability.

In conclusion, higher compliance is achievable with preallocated appointments, though the method described requires further evaluation especially for use in mobile screening.

We thank the staff of the Aylesbury Vale breast screening service for their help and Drs E Rose and M Orton for allowing us to study patients under their care.
1 Working Party on Breast Cancer Screening. Report to the health ministers of England, Wales, Scotland and Northern Ireland. London: HMSO, 1987. (Forrest report.)

2 Tabar L, Fagerberg CJG, Gad A, et al. Reduction in mortality from breas cancer after mass screening with mammography. Lancet 1985;i:829-32.

3 Verbeek ALM, Hendriks JNCL, Holland R, Mravunac M, Sturmans F, Day NE. Reduction in breast cancer mortality through mass screening with modern mammography, Lancet 1984; $;: 1222-4$.

4 United Kingdom Trial of the Early Detection of Breast Cancer Group. Firs results on mortality reduction in the UK trial of the early detection of breast results on mortality reduction in
cancer. Lancet 1988;ii:411-6.

5 Wilson A, Leeming A. Cervical cytology: a comparison of two call systems. Br Med f 1987;295:181-2.

(Accepted 26 April 1989)

\section{Reversible toxicity in poisoning with colloidal bismuth subcitrate}

\author{
Mark Hudson, N Ashley G Mowat
}

Gastrointestinal Research

Unit, Aberdeen Royal Infirmary, Aberdeen AB9 2ZB

Mark Hudson, MRCP, registrar

N Ashley G Mowat, FRCP, consultant physician

Correspondence and requests for reprints to: Dr Mowat.

BrMed f 1989;299:159

Encephalopathy after long term treatment with some bismuth salts has been widely reported, but toxicity from colloidal bismuth has not been recognised. We report the results of an overdose of colloidal bismuth.

\section{Case report}

A 27 year old man was admitted four hours after an overdose of $100 \mathrm{De}-\mathrm{Nol}$ (colloidal bismuth) tablets $(12 \mathrm{~g})$, paracetamol (blood concentration $30 \mathrm{mg} / \mathrm{l}$ ), and alcohol (blood concentration $162 \mathrm{mg} / \mathrm{l}$ ). Blood bismuth concentration was not measured. The next day he felt well and was discharged. Ten days later he was admitted to our unit complaining of anorexia, nausea, vomiting, general malaise, weakness of his legs, blurring of vision, thirst, and poor urinary output. $\mathrm{He}$ was dehydrated and unwell but had no fever or tachycardia. He had proximal leg muscle weakness with hyperreflexia and ankle clonus. His plantar reflexes, all senses, and both fundi were normal. $\mathrm{He}$ was lucid with no signs of encephalopathy.

Biochemical investigations yielded the following results: serum sodium $130 \mathrm{mmol} / \mathrm{l}$, serum potassium $4.3 \mathrm{mmol} / \mathrm{l}$, plasma bicarbonate $30 \mathrm{mmol} / \mathrm{l}$, plasma urea $69.9 \mathrm{mmol} / \mathrm{l}$, and plasma creatinine $2804 \mu \mathrm{mol} / \mathrm{l}$. Bismuth was detectable in his blood $(260 \mu \mathrm{g} / \mathrm{l})$, urine $(120 \mu \mathrm{g} / \mathrm{l})$, and stools $(26.9 \mathrm{mg} / \mathrm{g})$ but not in cerebrospinal fluid. Standard tests of liver function yielded normal results. An abdominal $x$ ray film showed opacification of the colon by ingested bismuth. An electroencephalogram showed non-specific slow wave changes over both hemispheres.

Renal failure and neurotoxicity induced by bismuth were diagnosed. After initial purgation with magnesium sulphate and rehydration with $0.9 \%$ saline haemodialysis was started. Five days later renal function had returned to normal and neurological signs resolved. The patient felt well. The table gives the blood urea, creatinine, and bismuth concentrations 96 days after ingestion.

\section{Comment}

Toxicity after ingestion of bismuth subgallate, subcitrate, and subsalicylate may result in tremors, confusion, myoclonus, ${ }^{2}$ encephalopathy with characteristic electroencephalographic changes, and fits. The mechanisms are not clear. Although colloidal bismuth subcitrate is much less easily absorbed, small quantities of it do enter the blood of animals
Blood urea, creatinine, and bismuth concentrations during 96 days after overdose with colloidal bismuth subcitrate

\begin{tabular}{|c|c|c|c|c|}
\hline $\begin{array}{c}\text { Days } \\
\text { after } \\
\text { ingestion }\end{array}$ & $\begin{array}{l}\text { Before } \\
\text { or after } \\
\text { dialysis }\end{array}$ & $\begin{array}{c}\text { Urea } \\
(\mathrm{mmol} / \mathrm{l})\end{array}$ & $\begin{array}{c}\text { Creatinine } \\
(\mu \mathrm{mol} / \mathrm{l})\end{array}$ & $\underset{(\mu \mathrm{g} / \mathrm{l})}{\begin{array}{c}\text { Blood } \\
\text { bismuth }\end{array}}$ \\
\hline 0 & \multirow{4}{*}{$\begin{array}{l}\text { Before } \\
\text { After }\end{array}$} & $<2.5$ & 97 & \\
\hline 11 & & $69 \cdot 9$ & 2804 & 260 \\
\hline 12 & & $69 \cdot 4$ & 2952 & 185 \\
\hline 12 & & $45 \cdot 7$ & 1693 & 84 \\
\hline 13 & $\left\{\begin{array}{l}\text { Before } \\
\text { After }\end{array}\right.$ & $\begin{array}{l}46 \cdot 3 \\
27 \cdot 8\end{array}$ & $\begin{array}{l}1938 \\
1165\end{array}$ & $\begin{array}{l}165 \\
160\end{array}$ \\
\hline \multirow{2}{*}{14} & \multirow{2}{*}{$\begin{array}{l}\text { Before } \\
\text { After }\end{array}$} & & & 200 \\
\hline & & $16 \cdot 7$ & 760 & 160 \\
\hline \multirow{2}{*}{15} & \multirow{2}{*}{$\begin{array}{l}\text { Before } \\
\text { After }\end{array}$} & & & 165 \\
\hline & & $9 \cdot 4$ & 460 & 150 \\
\hline \multirow{2}{*}{16} & \multirow{5}{*}{$\begin{array}{l}\text { Before } \\
\text { After }\end{array}$} & $10 \cdot 3$ & 475 & \\
\hline & & $<2 \cdot 5$ & 140 & 150 \\
\hline 20 & & $7 \cdot 7$ & 185 & 200 \\
\hline 60 & & 3.8 & 98 & 19 \\
\hline 96 & & $2 \cdot 7$ & 88 & 8 \\
\hline
\end{tabular}

^Measured by atomic absorption spectrometry.

and humans, with tissue binding in animal kidneys especially but also in the spleen, liver, brain, heart, and skeletal muscle. ${ }^{34}$ Bismuth may cause decreased glomerular filtration, reduced renal blood flow, and defects of proximal tubular reabsorption. ${ }^{5}$ In rats given high doses colloidal bismuth crosses the blood-brain barrier.

The absence of bismuth in cerebrospinal fluid may explain why the patient was not encephalopathic, and his transient neurological signs may have reflected his uraemia, itself a result of bismuth toxicity. The initial fall in blood bismuth concentration occurred after simple rehydration and purging. Reductions in blood bismuth concentration after haemodialysis were transient, the bismuth presumably being re-established from tissue stores but never reaching symptomatic concentrations.

The optimal treatment of overdose with colloidal bismuth is unknown. Within the first few hours absorption should be minimised by early hydration, gastric lavage (refused by this patient), and purging, even if the patient presents late as bismuth may well be absorbed from the colon. Chelating agents, such as penicillamine, may be effective in the early stages before tissue binding has occurred. Haemodialysis may be necessary, but whether this hastens tissue clearance of bismuth is uncertain. Even after large overdoses, as in this patient, the prognosis is good.

1 Rooney RC. Determination of bismuth in blood and urine. Analyst 1976;101 $749-52$.

Buge A, Rancurel G, Dechy H. Encéphalopathies bismuthiques: données étiologiques et pharmacologiques. Nouvelle Presse Medicale 1978;7:3531-4.

Buge A, Supino-Viterbo V, Rancurel G, Pontes C. Epileptic phenomena in bismuth toxic encephalopathy. I Neurol Neurosurg Psychiatry 1981;44:62-7. Lee SP, Lim TH, Pylbus J, Clarke AC. Tissue distribution of orally Lee SP, Lim TH, Pylbus J, Clarke AC. Tissue distribution of orally
administered bismuth in the rat. Clin Exp Pharmacol Physiol 1980;7:319-24. 5 Czerwinski AW, Ginn HE. Bismuth nephrotoxicity. Am J Med 1964;37:969-75. (Accepted 20 April 1989) 